\title{
Ancient Magic
}

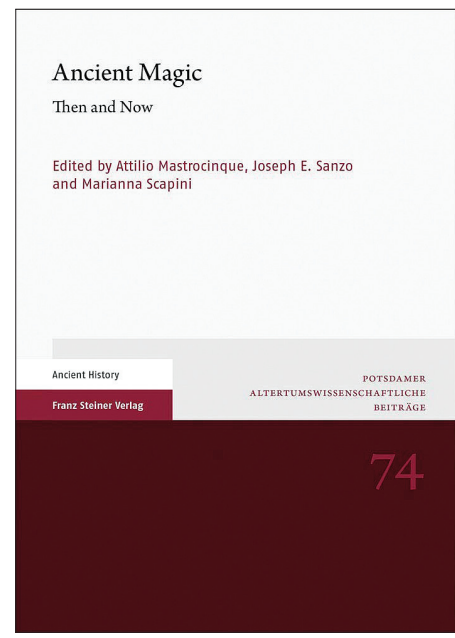

MASTROCINQUE, ATTILIO, SANZO, JOSEPH E. \& SCAPINI, MARIANNA (2020). Ancient Magic. Then and Now. Potsdamer Altertumswissenschaftliche Beiträge 74, Stuttgart: Franz Steiner Verlag. 451 pp., 82,00€. [ISBN: 978-3-5151-2796-7].

\section{DAVID FRANKFURTER BOSTON UNIVERSITY dtmf@bu.edu}

STARTING IN THE LATE 1980s, scholars of antiquity began to see an increasing flow of "magic volumes" emitting from various academic presses. "Magic volumes" are simply collections of papers that carry titles that relate to "magic", broadly conceived. Partly stimulated by the publication of Greek Magical Papyri in English, ${ }^{1}$ the earliest such collections ${ }^{2}$ represented initial explorations of the parameters of a "field" of

1. Betz, 1986.

2. Neusner, Frerichs and Flesher, 1989; Meyer and Mirecki, 1995; and the foundational Faraone and Obbink, 1991. 
magic: who were the "magicians," how do we generalize a "magic," what is the difference between "magical" and "religious" poetry, sacrifice, and speech, what did "magical" ritual involve, was there a "magical" worldview, and how to make sense of the multicultural features in the PGM. These volumes devoted sections to exposing the range of "magical" materials: amulets, lamps, assemblages, and of course the lively witnesses to a world of ancient "magic": Pliny, Apuleius, the Roman Twelve Tables, and the fullness of Christian and Jewish literature. Subsequent collections from the 1990s continued this kind of initial spadework while devoting somewhat more attention to the problematic definition of "magic" since Frazer. ${ }^{3}$

With the dawn of the third millennium we begin to see two trends in magic volumes. One is to explore "magic," or ritual traditions and archaeological assemblages, in particular regions or cultures or according to particular phenomenological themes. ${ }^{4}$ These editors were not satisfied, as it were, with "magic" broadly conceived but sought to nuance the term: what constitutes archaeological evidence for it? What dynamics are involved in the social experience of or ritual expressions of "magic"?

The other trend, however, has been to continue to publish loosely linked proceedings of conferences in which scholars interested in "magic" (broadly and impressionistically defined) can get together and give papers on their research. Let me be clear that, academically, these conferences have been essential for the emergence of the study of "magical" things from the dark and recondite preserves of Preisendanz, Barb, and Luck. And their published proceedings during the 1990s were essential in exploring what the field should encompass, to what degree we are working under an imaginary (or even self-defeating) rubric, and ways we might achieve greater terminological sophistication across the field. However, since these early publications we have seen an increasing number of magic volumes with no identifiable thematic or historical focus, little editorial guidance, and no particular

3. Schäfer and Kippenberg, 1997; Jordan, Montgomery and Thomassen, 1999; Mirecki and Meyer, 2001.

4. Thus, Marco Simón and Gordon, 2009 on the "Latin West"; Tardieu, Kerchove and Zago, 2013 on magical speech; Stratton and Kalleres, 2014 on women and "magic"; Eidinow and Gordon, 2019 on the definition of "witchcraft" in antiquity; De Haro Sánchez, 2015 on the magical writing; and Parker and McKie, 2018 (and, with less theoretical synthesis, Boschung and Bremmer, 2015) on material media representing "magic". Although seldom cited, I would add here Roper, 2004 on verbal and textual aspects of "charming" (see my review, Frankfurter, 2006). 
scholarly advancement of this field and its subjects - even if, occasionally, these volumes might contain unique and vital essays. ${ }^{5}$

The historiography I have hastily sketched here is meant to raise the question, what should a collection of scholarly papers on "magic" accomplish in the twenty-first century - and at this point in the evolution of (what is clearly) a field? Does "magic" remain just a vague, exotic rubric for people to get together and publish proceedings (on a topic that academic publishers crave)? Or has the field evolved to the extent that it can demand particular focuses and orientations in conferences and papers: in which philologists who study amulets or charms must thematize their materials; in which scholars interested in theurgy and intellectual aspects of "magic" must address ritual performance; in which the end-result of a conference might be to test and elaborate on a category? That is, should a "magic volume" actually demonstrate something, that subsequent conferences (and scholarship) can build upon?

And will "magic" continue to be used as a vague and common rubric, defined in multiple conflicting ways, for the collective study of ritual texts, strange artifacts, the boundaries of astrology and medicine, deviant cosmologies, and religious diversity in antiquity? In his 1992 address to the Lawrence (Kansas) conference, ${ }^{6}$ Jonathan Z. Smith made an unimpeachable case for the distortions (exoticism, primitivity, irrationality, crudeness) that "magic" imposes on materials, ideas, and rituals that, in their native cultural contexts, would not have been labelled mageia or magia at all. ${ }^{7}$ Since the publication of this essay, Randall Styers and Bengt-Christian Otto have condemned in the more detailed terms of modern intellectual history the casual academic labelling of things as "magic". I certainly don't hold up my 2019 Guide to the Study of Ancient Magic as the last word on this issue, but the way that I sought to build on scholarly discussions of ancient religious polemic, on the archaeology of ritual things and manuals, and on the phenomenology of ritual action and speech, was meant to "move things forward" - to stimulate some consensus in the critical discussion of "magic."

It is to the credit of Mastrocinque, Sanzo, and Scapini that they have insisted that every author define "magic" for him or herself somewhere in each paper. Some of these definitions depend on a now-untenable dichotomy between "magic" and

5. Bremmer and Veenstra, 2002; Ciraolo and Seidel, 2002; Shaked, 2005; Bohak, Harari and Shaked, 2011; Petropoulos, 2014; Bortolani et al., 2019.

6. Published as Meyer and Mirecki, 1995.

7. Smith, 1995.

8. Styers, 2004; Otto, 2011 and 2013.

9. Frankfurter, 2019. 
religion (García), or on a circular equation between "magic" and anything contained in the PGM (Cesteros). Others claim to draw on (yet never test the boundaries of) an intriguing definition offered by Alvar Nuño and Alvar Ezquerra in their introductory essay: "A pragmatic and instrumental subsystem of religion meant to alleviate situations perceived to be crises by the individual, who decides to resort to an intermediary or other type of semi-institutionalized pragmatic solution" (p. 49, cited e.g., by Pérez-Jiménez). For Cordovana "magic" is understood simply as the concept of natural sympathies in Pliny. Some of the more senior scholars - Faraone, Dasen, Mastrocinque - don't bother with definitions but simply discuss what they discuss. But the problem in this strategy (and even more in the pro forma declaration of some definition) is that it leaves open the fundamental question of a volume entitled $A n$ cient Magic: Then and Now: Why is this an example of "magic"? Why are dice-games (Dasen), domestic dream rites (Faraone, Mastrocinque), breast milk and menstrual blood (Pedrucci), or even lamps (Diosono) examples of "magic"? What do they have in common? Is this equivalent to discussing scorpions, lobsters, beetles, and ants as all members of the phylum arthropeda or (on the other hand) to discussing the pencil, the tissue, the cup, the book, and the dead moth near your window as "stuff to put away" - that is, is "magic" a grouping based on critical similarities, or one based on vague convenience? Does "magic" actually suggest common elements, or does it just gather things that are vaguely exotic? Does "magic" help the understanding or contextualization of dice-games, oneiromancy, or lamps (or the PGM) - say, by relating one to another?

In attempting to build upon current discussions in the broad field of "magic"studies the volume opens with two essays that seek to defend a category "magic." Sanzo acknowledges the criticisms of the modern term "magic" levelled by Smith and Otto, inter alia, as well as the "qualitative" or aesthetic uses of the term that I advocate in the Guide. Yet he seeks to preserve a more categorical meaning to "magic" since (he argues) alternative terms are no better, since every broad category has a nefarious history, and - most of all - since he sees a congruence between how ancient people regarded religious or ritual deviance and our modern category. ("Magic," he implies then, should embrace most usefully ancient notions of deviant ritual practices). However, what this essay does not do is precisely what I have been outlining: a constructive synthesis of the extremely diverse materials contained in this particular volume. If classifying oneiromancy as "magic" when little evidence exists that anyone doing it thought of it as deviant ritual practice fundamentally distorts its cultural significance, then how is "magic" defensible? How does it help us understand the place of oneiromancy in culture, or domestic practice, or religion in general? To use "magic" 
as a category requires a theory of magic as a descriptive term - of its boundaries and characteristics - and not simply the defense of an old-fashioned status quo...

The second programmatic essay is that of Alvar Nuño and Alvar Ezquerra, who provide the strong definition quoted above: a "subsystem of religion meant to alleviate situations perceived to be crises" (this definition - this strategic delimitation of what could be productively labelled "magical" - can bring together a great range of amulets and ritual librettos, but it would probably exclude divination spells and the innumerable PGM rites designed to produce theophanies). But then, the authors shift strangely to define a more extreme category that they call - inexplicably - "pure magic". They claim this term as a euphemism for what anthropology calls "witchcraft": a combination of "internal, biological, mystical power" and various ritual gestures and acts imagined from the folk (emic) perspective as producing coercive power. Why this amorphous range of beliefs should be grouped under such a category, why it should be related to "magic" (as they define it) as more "pure," and how this category can help interpret any of the diverse materials in this volume are questions left frustratingly unaddressed.

Following these essays, the rest of the volume concerns philological, literary/ philosophical, textual, or archaeologically circumscribed studies that either presume that they belong in a magic volume or rely on some definition of "magic" to explain their utility. Thus, Cordovano writes on "Pliny the Elder between Magic and Medicine"; Salin on "Anti-Witchcraft Rituals Against Depression in Assyro-Babylonian Therapeutic Texts" (where anti-witchcraft rites are ipso facto "magic"); and Mastrocinque on a Croatian lamella that he (rather imaginatively) connects to a Jewish necromancy - again, where such rituals are obviously "magic." The dizzying array of topics continues with Sánchez Natalías on an inscription on a lead container from the Anna Perenna deposits; Marco Simón on defixiones from aquatic sites in Britain; Diosono on the "magical" value of lamps left in sanctuaries; and Carbó García on some ritual artifacts from Roman Dacia. There is the hint of a productive comparative theme, divination, in the papers of Mastrocinque, on a putative Jewish necromancy; Dasen, on the culture of ancient dice-throwing; and Faraone, on material accoutrements of domestic oneiromancy (and later, those of Martín Hernández and Costanza on divination manuals used by specialists). But then the papers move on to cover women's erotic spells (Suárez de la Torre), uses of daimōn and angel to refer to deities in the PGM (improbably attributed to Judaism; Canzobre Martínez), and 
the ostensible paradox of the "magical hymn" (Blanco Cesteros), a paper that barely addresses the recent magisterial study by Lluba Bortolani. ${ }^{10}$

Subsequent papers address (in order): breast milk and menstrual blood as ritual substances (Pedrucci), the polarity of right and left in astrology and ritual healing (Pérez-Jiménez), theurgy in the Chaldean Oracles (Ferrari), "magic" in Julius Africanus (Mecella), papyrological evidence for the use of Homer for divination (Martín Hernández), continuities in divination practices between early Roman and later Byzantine texts (Costanza), meanings of the medieval term Zouber in a medieval legend of Tristan (Foschi Albert), the versions of the "Secret Book of Moses" contained in the PGM (Dorandi), and the roots of the Circe figure in ancient Near Eastern literature (Martino Lucarini).

The diversity of these papers quite overflows the three titles into which the editors have distributed them. Magic as a Category: Voices from the Past, Voices from the Present is supposed to link Cordovana's study of Pliny with the two programmatic papers on the modern use of the term "magic". Interpreting Magical Texts and Objects contains the bulk of the other papers. The last seven are grouped under the title Transmission of Ancient Magic, although the concept of transmission seems quite different between Martín Hernández on Sortes Homericae papyri and Martino Lucarini on ancient predecessors to the character Circe. Could the editors have highlighted this variation? Indeed, the volume cries out for a constructive assessment of papers on clearly evident themes, like material artifacts (and why one might apply the word "magic" to them), on verbal and textual charms, on divination, on esotericism, and on literary uses of mageia or constructions of ambiguous ritual forces. It is in this kind of comparison - of lamellae, shrine lamps, even menstrual blood as examples of some larger phenomenon - that the term "magic" is either artificially constructed or critically substantiated. Some of the best papers in this volume (Dasen, Faraone, Marco Simón, Pedrucci, Martín Hernández) make minimal efforts to relate their studies to "magic," while those that make the most explicit efforts to demonstrate "magicality" (e.g., Salin, Diosono, Carbó García, Blanco Cesteros) end up displaying the pitfalls of the term: that it promotes inaccurate dichotomies and exoticizes everyday artifacts, as Jonathan Z. Smith argued in the 1992 lecture.

If "magic" is to have any more meaning than as a pretext to hold international conferences, then organizers and editors must make a point of applying it, testing it, and sub-dividing "magic" into themes and patterns of value. What sorts of things seem to substantiate "magic"? Even more, editors must use their collections (as op-

10. Bortolani, 2016. 
posed to abstract reasoning) to make a cumulative case for the application of "magic". But if Ancient Magic: Then and Now comprises everything from Pliny to Tristan, from Croatian necromancy to Assyro-Babylonian verbal therapy, from breast milk to the PGM, then this rubric most likely has little descriptive or humanistic value.

\section{Bibliography}

Betz, Hans D. (1986). The Greek Magical Papyri in Translation. Chicago: The University of Chicago Press.

Bohak, Gideon, Harari, Yuval \& Shaked, Shaul (eds.) (2011). Continuity and Innovation in the Magical Tradition. Jerusalem Studies in Religion and Culture 15. Leiden: Brill.

Bortolani, Ljuba M. (2016). Magical Hymns from Roman Egypt: A Study of Greek and Egyptian Traditions of Divinity. Cambridge: Cambridge University Press.

Bortolani, Ljuba M., Furley, William D., Nagel, Svenja \& Quack, Joachim F. (eds.) (2019). Cultural Plurality in Ancient Magical Texts and Practices: Graeco-Egyptian Handbooks and Related Traditions. Oriental Religions in Antiquity 32. Tübingen: Mohr Siebeck.

Boschung, Dietrich and Bremmer, Jan N. (eds) (2015). The Materiality of Magic. Morphomata 20. Paderborn: Wilhelm Fink.

Bremmer, Jan N. \& Veenstra, Jan R. (2002). The Metamorphosis of Magic from Late Antiquity to the Early Modern Period. Groningen Studies in Cultural Change 1. Leuven: Peeters Publishers.

Ciraolo, Leda \& Seidel, Jonathan (eds.) (2002). Magic and Divination in the Ancient World. Magic and Divination in the Ancient World. Ancient Magic and Divination 2. Leiden: Brill.

Eidinow, Esther \& Gordon, Richard L. (eds.) (2019). Special Volume on Narrating Witchcraft: Agency, Discourse and Power. Magic, Ritual, and Witchcraft, 14.1-2, pp. 1-113, 143-254.

Faraone, Christopher A. \& Obbink, Dirk (eds.) (1991). Magika Hiera: Ancient Greek Magic \& Religion. New York: Oxford University Press.

Frankfurter, David (2006). Review of Roper, Jonathan (ed.) (2004). Charms and Charming in Europe. New York: Palgrave Macmillan. Numen, 53, pp. 392-96.

Frankfurter, David (ed.) (2019). Guide to the Study of Ancient Magic. Religions in the GraecoRoman World 189. Leiden: Brill.

Haro Sánchez, Magali (ed.) (2015). Écrire la Magie dans l'antiquité. Actes du Colloque International (Liège, 13-15 Octobre 2011). Papyrologica Leodiensia 5. Liège: Presses Universitaires de Liège.

Jordan, David R., Montgomery, Hugo \& Thomassen, Einar (eds.) (1999). The World of Ancient Magic: Papers from the First International Samson Eitrem Seminar. Papers from the Norwegian Institute at Athens 4. Bergen: Norwegian Institute at Athens. 
Marco Simón, Francisco \& Gordon, Richard L. (eds.) (2009). Magical Practice in the Latin West: Papers from the International Conference (Zaragoza, 30 Sept. - 1st Oct. 2005). Religions in the Graeco-Roman World 168. Leiden: Brill.

Meyer, Marvin W. \& Mirecki, Paul A. (eds.) (1995). Ancient Magic and Ritual Power. Religions in the Graeco-Roman World 129. Leiden: Brill.

Mirecki, Paul A. \& Meyer, Marvin W. (eds.) (2001). Magic and Ritual in the Ancient World. Religions in the Graeco-Roman World 141. Leiden: Brill.

Neusner, Jacob, Frerichs, Ernest S., \& McCracken Flesher, Paul V. (eds.) (1989). Religion, Science, and Magic. In Concert and in Conflict. New York: Oxford University Press.

Otto, Bernd-Christian (2011). Magie, Rezeptions- und diskursgeschichtliche Analysen von der Antike bis zur Neuzeit. Religionsgeschichtliche Versuche und Vorarbeiten 57. Berlin: De Gruyter.

Otto, Bernd-Christian (2013). Towards Historicizing "Magic" in Antiquity. Numen, 60, pp. 308-347.

Parker, Adam \& McKie, Stuart (eds.) (2018). Material Approaches to Roman Magic. Occult Objects and Supernatural Substances. Themes in Roman Archaeology 2. Oxford: Oxbow Books.

Petropoulos, John C. (ed.) (2014). Greek Magic. London \& New York: Routledge.

Roper, Jonathan (ed.) (2004). Charms and Charming in Europe. Houndmills: Palgrave Macmillan.

Schäfer, Peter \& Kippenberg, Hans G. (eds.) (1997). Envisioning Magic: A Princeton Seminar and Symposium. Envisioning Magic. Numen Supplements 75. Leiden: Brill.

Shaked, Shaul (ed.) (2005). Officina Magica: Essays on the Practice of Magic in Antiquity. Officina Magica. Instutitute of Jewish Studies Studies in Judaica 4. Leiden: Brill.

Smith, Jonathan Z. (1995). Trading Places. In Meyer \& Mirecki, 1995, pp. 13-27.

Stratton, Kimberly B. \& Kalleres, Dayna S. (eds). (2014). Daughters of Hekate: Women and Magic in the Ancient World. New York: Oxford University Press.

Styers, Randall (2004). Making Magic: Religion, Magic, and Science in the Modern World. New York: Oxford University Press.

Tardieu, Michel, Van den Kerchove, Anna \& Zago, Michela (eds.) (2013). Noms barbares 1: Formes et contextes d'une pratique magique. Bibliothèque de l'École des Hautes Études, Sciences religieuses 162. Turnhout: Brepols. 